\title{
Memulihinan Wibawa Allah sebagai Gembala Israel: Kritik atas Para Pemimpin Yehuda di Yehezkiel 34
}

\author{
Eko Riyadia, \\ Fakultas Teologi Universitas Sanata Dharma, Yogyakarta, Indonesia ${ }^{a}$ \\ ekoriyadi@gmail.com ${ }^{1}$
}

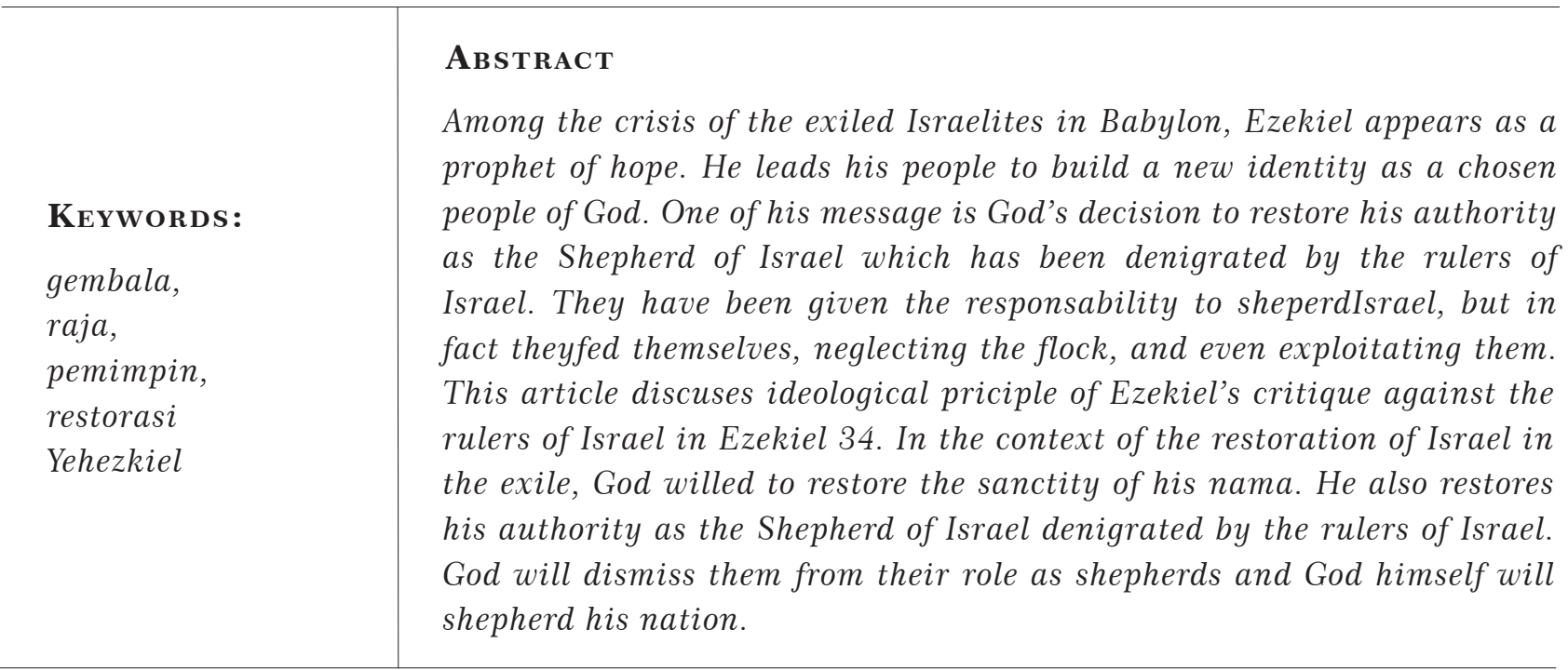

\section{PENGANTAR}

Para nabi Israel merupakan figur-figur kharismatik, para utusan Allah untuk menyampaikan sabda dan kehendakNya, terutama ketika Israel hidup jauh dari ketaatan dan kesetiaan kepada Allah sebagaimana dituntut dalam perjanjian antara Allah dan Israel. Seorang nabi diutus untuk memulihkan wibawa Yahwe sebagai Allah yang berdaulat atas Israel yang telah diciderai oleh pelanggaran dan ketidaksetiaan Israel. Para nabi muncul terutama ketika Israel hidup sebagai sebuah kerajaan, baik ketika Israel masih hidup sebagai satu kerajaan maupun setelah perpecahan menjadi dua kerajaan. Mereka tampil dalam konteks sosio-religio-politis Israel yang parah karena Israel telah meninggalkan kesetiaan kepada Allah dan mereka diutus oleh Allah untuk memulihkan ketaatan dan kesetiaan Israel kepada Allah. Para pemimpin Israel (raja, imam, dan nabi) sering menjadi objek kritik para nabi karena mereka yang semestinya menggembalakan Israel ternyata justru menyesatkan bangsa kepunyaan Allah. Cara yang ditempuh oleh para nabi untuk mengembalikan Israel ke dalam ketaatan dan kesetiaan pada Allah antara lain adalah dengan menegur, mengkritik dan menubuatkan malapetaka atas ketidaksetiaan Israel kepada Allah. 
Kritik para nabi atas ketidaksetiaan Israel tampil dalam berbagai bentuk, seperti kritik atas penyembahan berhala, penumpahan darah, perilaku moral yang tidak benar, serta pelanggaran terhadap prinsip keadilan sosial. Dalam kenyataannya, para nabi adalah juga para kritikus sosial yang berakar dalam situasi sosio-politik bangsanya, menjadi seperasaan dengan rakyat yang tertindas, melihat ketidakadilan dalam hidup bersama, dan menyampaikan kritik-kritik keras terhadap para pelaku ketidakadilan.

Yehezkiel adalah salah seorang nabi besar yang muncul dalam tradisi kenabian Israel. Berbeda dari buku-buku kenabian lain, kitab Yehezkiel tidak menyediakan sebuah pembukaan formal yang mencantumkan konteks historis pelayanannya. ${ }^{1}$ Situasi sosio-historis yang dihadapinya sedikit berbeda dengan nabi-nabi terdahulu karena ia melayani orang-orang Yehuda yang ada di tanah pembuangan. Pada umumnya diyakini bahwa Yehezkiel menyampaikan pesannya kepada mereka yang ada di tanah pembuangan sehingga juga perlu dibaca dan dimengerti dalam konteksnya, yakni konteks Babilonia. ${ }^{2}$ Ia menjadi nabi Allah yang menegur sekaligus meneguhkan umat Allah dengan seruan-seruan penghiburan dan pemulihan atas Israel. Dalam upaya untuk membangun kembali identitas religiusnasional orang-orang terbuang, Yehezkiel menyerang orang-orang yang tinggal di Yerusalem yang menganggap diri menjadi pewaris sah dari janji Allah kepada leluhur. Ia mengkritik para gembala Israel yang justru menggembalakan dirinya sendiri.

Block, Daniel I., Beyond The River Chebar. Studies in Kingship and Eschatology in the Book of Ezekiel, Cambridge: James Clarke \& Co. 2013, 10

2 Martti Nissinen, "(How) Does the Book of Ezekiel Reveal Its BabyIonian Context?" Die Welt des Orients 45 (2015): 86.
Artikel ini bermaksud untuk mempelajari dasar ideologis dari kritik nabi Yehezkiel di Yehezkiel 34 atas perilaku para pemimpin Israel yang dinilai telah menyimpang dari arah yang ditetapkan oleh Allah, yakni karena mereka menggembalakan diri sendiri dan tidak bertanggung jawab untuk menggembalakan kawanan yang dipercayakan oleh Allah kepada mereka.

\section{MEMBANGUN IDENTITAS BARU}

Warta kenabian Yehezkiel terkait erat dengan situasi Yehuda yang dilayaninya. Masa kenabian Yehezkiel dimulai pada tahun kelima pembuangan Babilonia ketika ia sedang berada bersama-sama dengan orangorang buangan di tepi sungai Kebar dan menerima penglihatan dari Allah (Yeh. 1:13). Ia dibuang bersama dengan raja Yoyakin dan para pembesar negeri tahun 596 SM. Sebagian besar penduduk Yehuda berada di pembuangan Babilonia setelah dikalahkan oleh Nebukadnezar. Ia mengalami periode dramatis yang dimulai dari tahun-tahun menjelang kehancuran Yerusalem sampai ia menerima tugas kenabian di tanah pembuangan. ${ }^{3}$ Yehuda kehilangan orangorang kelas atas (bangsawan, cerdik pandai, perajin) karena mereka dibuang ke negeri Babilonia. Sebagian masyarakat masih tinggal di Yehuda dan memiliki raja baru yakni raja Zedekia yang diangkat oleh Babilonia. Pembuangan ke tanah asing menjadi saat kritis baik bagi orangorang yang dibuang maupun bagi mereka yang masih tinggal di Yehuda. Pertanyaan tentang siapa yang akan mewarisi tanah di masa depan menjadi pertanyaan yang dipertengkarkan oleh orang-orang di pembuangan dan mereka yang masih tinggal

\footnotetext{
D. Rom-Shiloni - Corrine Carvalho. "Introduction," Die Welt des
} Orients 45 (2015): 4. 
di Yehuda. ${ }^{4}$ Masing-masing merasa menjadi pewaris sah atas tanah leluhur tersebut. Mereka yang dibuang harus melihat kembali identitas religius-nasional mereka setelah mereka tidak berada lagi di tanah leluhur. Kini mereka hidup di tanah pembuangan, di tengah-tengah bangsa yang tidak menyembah Allah Israel, tetapi menyembah dewa-dewi mereka sendiri. Kenyataan ini menjadi tantangan besar bagi orang-orang Yehuda di pembuangan karena ikatan perjanjian dengan Yahwe dalam satu ikatan satu bangsa, satu tradisi dan satu kenisah menjadi semakin luntur ketika mereka tidak lagi memiliki tanah yang semula mereka tempati dan tidak lagi memiliki Bait Allah Yerusalem sebagai pengikat tradisi religius mereka. Kaidah trianggolaris Allah, umat, dan tanah yang sudah terbangun dalam konsep teologis dalam sejarah Israel sejak Abraham kini ada dalam krisis besar, terutama bagi orang-orang buangan.

Dalam masa pembuangan itu, Yehezkiel menerima banyak penglihatan dari Allah yang harus disampaikannya kepada umat, yakni "orang-orang buangan, temanteman sebangsamu" (Yeh. 3:11). Yehezkiel terus melayani mereka setidaknya sampai tahun yang kedua puluh tujuh dari masa pembuangan, yaitu tahun 571 SM, ketika Nebukadnezar masih memerintah. Karena ia melayani sebagai nabi di tengah-tengah umat Yehuda yang sedang dalam pembuangan, panggilan Yehezkiel sangat erat terkait dengan nasib bangsa Yehuda yang harus memasuki babak baru dalam cara hidup dan cara beriman mereka. Salah satu tantangan Israel di pembuangan adalah menemukan kembali kekokohan kepemimpinan yang

4 C. A. Strine, Sworn Enemies. The Divine Oath, the Book of Ezekiel, and the Polemics of Exile, Berlin: De Gruyter, 2013,177. telah runtuh karena pembuangan. ${ }^{5}$ Tidak ada lagi figur yang menjadi raja yang berwibawa karena Yoyakin yang ikut dibuang ke Babilonia tidak dapat lagi menjalankan tugas dalam kemerdekaan sebagai seorang raja. Sementara di tanah Yehuda, Zedekia justru melakukan banyak pelanggaran yang akan dikiritik oleh Yehezkiel.

Di tengah-tengah kaum terbuang, Yehezkiel memegang peran sebagai pembangun identitas baru dengan membaca kembali janji-janji Allah terdahulu dalam konteks pembuangan. Ketika orang-orang yang tertinggal di Yerusalem menganggap bahwa orang-orang buangan telah diserakkan oleh Allah sehingga tidak mewarisi lagi tanah dan janji Allah kepada leluhur, Yehezkiel meyakinkan orang-orang buangan bahwa merekalah yang pada akhirnya akan mewarisi janji-janji Allah. Yehezkiel mengidentifikasi diri dengan orang-orang Yehuda di pembuangan dengan menampakkan kontras antara mereka yang dibuang bersama raja Yoyakhin dan mereka yang masih tinggal di Yehuda bersama raja Zedekia. ${ }^{6}$ Yehezkiel banyak mengarahkan kritiknya pada para pemimpin dan rakyat di Yerusalem, sementara ia menyerukan penghiburan bagi orang-orang di tanah pembuangan. Ada upaya membangun legitimisasi diri dan mendelegitimasi kelompok lain dalam upaya menemukan identitas baru bangsa terbuang. Perbandingan antara Yohakhin sebagai pucuk pohon aras dan Zedekia sebagai pohon anggur (Yeh 17) dan seranganserangan langsung terhadap Zedekia (12:816; 21:23-32) dan Yerusalem (Yeh 8-11) menampakkan kecondongan Yehezkiel untuk lebih mendukung orang-orang di

\footnotetext{
S. Tsang, "A Call to Leadership: Character Study of Ezekiel and the Temple Staff," CGST 44 (2008): 152.

6 D. Rom-Shiloni, "Ezekiel as the Voice of the Exiles and Constructor of Exilic Ideology," Hebrew College Annual 76 (2005): 1-45.
} 
tanah pembuangan. Serangan-serangan terhadap para pemimpin di Yerusalem merupakan strategi untuk mengkristalkan kesadaran orang-orang buangan bahwa merekalah umat Allah yang sejati.

Yehezkiel menginterpretasikan ulang konsep trianggolaris Allah, bangsa, dan tanah yang menjadi landasan bagi identitas Israel. ${ }^{7}$ Para pendudukYerusalem (yaknimerekayang tidak dibuang) meyakini bahwa merekalah pewaris janji Allah kepada Abraham yang akan menerima tanah. Mereka beranggapan bahwa merekalah yang memiliki hak yang sah atas tanah yang mereka tempati. Bagi mereka, orang-orang yang dibuang ke tanah asing telah kehilangan identitas religiusnasional mereka sebagai umat Allah. ${ }^{8}$ Di sisi lain, Yehezkiel menyerukan kepada orangorang buangan bahwa Allah menjauhkan mereka dari Yerusalem (11:16), tetapi akan memberikan tanah sebagai warisan bagi mereka (11:17). Meski mereka terbuang, mereka tidak menghamba kepada dewa-dewi asing dan tidak disingkirkan dari hadapan Allah, tetapi mereka akan dikumpulkan oleh Allah dari antara bangsa-bangsa untuk memperoleh kembali tanah (11:17). Mereka akan kembali ke Israel, akan menyucikan tanah leluhur dari kekejian dan Allah akan memperbarui hati mereka (11:18-19). Kini mereka jauh dari tanah leluhur, tetapi senyatanya mereka tidak terpisah dari Allah. Dalam semua itu, Allahlah yang mengambil inisiatif untuk menyatukan diri dengan orang-orang buangan (Yeh. 11:16-21; 36:32). Yehezkiel yang diutus menjadi nabi Allah membangun kembali komunitas orangorang terbuang sebagai umat Allah yang eksklusif sehingga ia bisa disebut sebagai

\footnotetext{
Terry R. Clark, I Will Be King over You. The Rhetoric of Divine Kingship in the Book of Ezekiel. Piscataway, NJ: Gorgias Press, 2014, 245.

8 D. Rom-Shiloni, "Ezekiel as the Voice of the Exiles,..." 15
}

suara orang-orang terbuang dan pembangun ideologi pembuangan yang baru. ${ }^{9}$ Kaum buangan harus mulai mengorganisir kembali hidup mereka dan menemukan identitas nasional mereka sebagai sebuah minoritas di tengah masyarakat asing yang jauh lebih kuat daripada mereka.

Di beberapa tempat, Yehezkiel menubuatkan rencana Allah untuk memulihkan kembali umat-Nya. Rangkaian nubuat di Yeh. 34-48 menampilkan masa depan yang akan dialami oleh orang-orang yang tetap setia kepada Allah selama masa pembuangan. ${ }^{10}$ Mereka yang serupa tulangtulang kering akan diberi hidup kembali (Yeh. 37). Dalam gambaran mitologis, Allah akan mengalahkan kuasa kekacaubalauan untuk mengembalikan kejayaan Israel. ${ }^{11}$ Allah akan bertindak dan memulihkan wibawaNya atas Israel. Dalam kebutuhan untuk membangun identitas religius politis yang baru tersebut, salah satu pesan khusus yang diserukan oleh Yehezkiel adalah kritikan terhadap para gembala Israel, yakni para pemimpin Israel yang diserahi tanggung jawab oleh Allah untuk memimpin Israel. Mereka yang ditugaskan menjadi gembala telah mengecewakan Allah karena mereka justru menggembalakan diri sendiri dengan melakukan penindasan dan ketidakadilan kepada rakyat (Yeh. 34). Dengan keras, Yehezkiel mengecam gembala-gembala yang tidak hidup sesuai dengan tugasnya. Dalam situasi berat hidup mereka sebagai bangsa, para pemimpin tidak menunjukkan jalan menuju pada kehidupan, tetapi justru menindas dan menghisap mereka yang bergantung pada kepemimpinan mereka.

\footnotetext{
9 D. Rom-Shiloni,"Ezekiel as the Voice of the Exiles," 15

10 Terry R. Clark, I Will Be King over You. The Rhetoric of Divine Kingship, 245

${ }^{11}$ C. A. Strine - C. L. Crouch, "Yhwh's Battle against Chaos in Ezekiel: The Transformation of Judahite Mythology for a New Situation," Journal of Biblical Literature 132 (2013): 883.
} 
Tudingan keras dialamatkan pada para pemimpin Yehuda yang masih tinggal di Yerusalem, tetapi dengan cara demikian Yehezkiel juga menunjukkan kepada orangorang di tanah pembuangan pemimpin seperti apakah yang semestinya mereka miliki. Selain mengecam mereka, Yehezkiel juga memberikan sebuah wacana normatif kepada para gembala tentang apa yang semestinya mereka lakukan. Solusi tersebut menjadi panduan yang jelas untuk aksi pertobatan dan pembaharuan, sehingga pelaku ketidakadilan sosial dapat kembali ke jalan yang benar.

Kritik Yehezkiel atas para pemimpin Israel tumbuh dari pengalaman hidupnya yang mengalami pembaharuan oleh raja Yosia sebelum pembuangan (2 Raj. 23:1-25) sekaligus juga ketidaksetiaan para pemimpin sesudahnya, keruntuhan moral Israel. Ia juga melihat kekuatan-kekuatan besar di luar Israel yang saling berebut pengaruh seperti Asyur, Babilonia dan Mesir. Ia mengalami pergulatan antara keputusasaan dan harapan, perasaan ditinggalkan oleh Allah dan sekaligus jaminan akan kehadiran-Nya. ${ }^{12}$ Apa yang ia lihat dan alami menjadikannya sebagai nabi yang menyuarakan suara Allah yang menuntut kembali otoritas-Nya sebagai gembala yang sudah dicemarkan oleh para pemimpin Israel.

\section{KRITIK TERHADAP PARA GEMBALA ISRAEL}

Kritik terhadap para pemimpin tidak lepas dari upaya Yehezkiel untuk membangun kembali tata kepemimpinan baru bagi Israel di tanah pembuangan setelah hancurnya

\footnotetext{
2 Ignatius M. C. Obinwa, "I Shall Feed Them with Good Pasture" (Ezek 34:14): The Shepherd Motif in Ezekiel 34. Its Theological Import and Socio-political Implications, FB 125; Wurzburg: Echter, 2012, 55.
}

kepemimpinan raja-raja Yehuda yang dianggap gagal menggembalakan Israel. Setiap pemimpin bertanggung jawab secara etis dan juga harus secara etis dapat mempertanggungjawabkan semua bentuk interaksinya dengan orang-orang yang dipimpin. ${ }^{13}$ Dalam kepemimpinan Israel, seorang pemimpin tidak hanya bertanggung jawab kepada orang-orang yang dipimpin, tetapi terlebih kepada Allah yang memberikan tanggung jawab kepemimpinan tersebut. Yehezkiel melihat bahwa para pemimpin Israel telah meninggalkan tanggungjawab etik mereka untuk memimpin Israel atas nama Allah. Zedekia yang diangkat menjadi raja di Yerusalem untuk menggantikan Yoyakin menjadi simbol para pemimpin yang diserang dengan keras oleh Yehezkiel. Aneka pelanggaran etis dituduhkan kepada mereka seperti penyembahan berhala, penumpahan darah, dan kecemaran seksual yang melawan Hukum Kekudusan. Yehezkiel memiliki gambaran yang negatif tentang raja-raja Yehuda. ${ }^{14}$

Alih-alih membawa Israel kepada kesetiaan pada Allah, para pemimpin justru menjadi contoh negatif dengan menghambakan diri pada berhala-berhala. Wibawa Allah sebagai penjamin hidup Israel dirongrong justru oleh mereka yang diserahi tanggung jawab untuk menuntun Israel. Yehezkiel mengkritik praktek penyembahan berhala yang dilakukan oleh para penatua Israel di Bait Allah. Mereka mendirikan patung-patung berhala di pelataran pintu gerbang (ay.3), melukis gambar-gambar binatang melata dan binatang-binatang lain yang menjijikkan (ay.10). Tua-tua Israel mempersembahkan ukupan kepada dewadewi (ay.11-13). Perempuan-perempuan

\footnotetext{
${ }^{13}$ Chaudhary I. Sarwar, "Future of Ethically Effective Leadership," Journal of Business Ethics 113 (2013): 82.

14 Block, Daniel I., Beyond The River Chebar..., 11.
} 
memuja dewa Tamus (ay.14). Para lelaki membelakangi Bait Allah dan menghadap ke timur untuk bersujud kepada matahari (ay.16). Kemakmuran dan kesejahteraan, serta kejayaan bangsa-bangsa besar di sekitar Israel telah membuat mereka meyakini bahwa allah-allah yang disembah oleh bangsa-bangsa itu adalah allah-allah yang benar dan kuat sehingga orang-orang Yehuda pun menghambakan diri pada dewadewi asing untuk memperoleh kesejahteraan yang sama. ${ }^{15}$ Praktek-praktek demikian oleh Allah dianggap sebagai perbuatan-perbuatan kekejian yang membuat Allah menjauhkan diri dari tempat kudus-Nya (ay.6). Allah akan membalas mereka dan tidak akan berbelas kasih (ay.18). Kehancuran Yehuda dan pembuangan ke Babilonia diartikan sebagai bentuk pembalasan Allah, tetapi praktek kekejian yang dilakukan oleh para pemuka Yehuda di Bait Allah kini juga dilakukan oleh para pemuka Yehuda di tanah pembuangan $(14: 2.4)$.

Di Yeh 1-33, kritik Yehezkiel terutama ditujukan kepada mereka yang disebut raja (hammélek) maupun pemimpin (näŝ́̂') yang diserang oleh Yehezkiel karena telah melakukan ketidakadilan dan pelanggaran terhadap perjanjian dengan Allah. Para pemuka rakyat di Yerusalem merancang kedurjanaan dan menaburkan nasihat jahat di kota (11:1-2), merampas tanah orang-orang yang dibuang ke Babilonia, membunuh orang-orang dan memenuhi kota dengan jasad mereka (11:6), para pemimpin menumpahkan darah (22:6), dan memutus ikatan kekerabatan mereka (22:712). Mereka menjadi gembala-gembala yang menggembalakan diri sendiri dan gagal melindungi domba-domba yang lemah dan sakit (Yeh. 34). Alih-alih menjaga dan

15 S. Tsang, "A Call to Leadership," 156. mempersatukan, mereka justru melukai dan mencerai-beraikan. Para pemimpinlah yang dianggap paling bertanggung jawab atas berjimbunnya ketidakadilan sosial di tengah-tengah Yehuda. Dalam kacamata Yehezkiel, tidak ada raja Israel yang layak menyandang gelar raja sehingga mereka hanya disebut sebagai "pemimpin" karena hanya Allahlah Raja yang benar. ${ }^{16}$ Tidak digunakannya sebutan raja oleh Yehezkiel tidak pertama-tama karena mereka tidak memiliki raja, melainkan karena para raja tidak bertindak seturut dengan kedaulatan Allah. Meskipun demikian, tampaknya Yehezkiel mempergunakan istilah raja dan pemimpin sebagai dua kata yang saling menggantikan. ${ }^{17}$

Kegagalan para pemimpin mendatangkan konsekuensi-konsekuensi berat (Yeh. 13). Allah akan menurunkan mereka dari jabatan mereka dan menghancurkan mereka. Seorang raja bertanggung jawab untuk menjamin keadilan dan kesejahteraan sehingga rakyat hidup dalam damai sejahtera. Ia berkewajiban menjaga rakyatnya dari musuh-musuh yang menindas dan menyengsarakan. Karena seorang raja Israel berkuasa atas nama Allah, ia juga harus menjamin bahwa Israel taat setia kepada Allah. Untuk itu, ia sendiri harus selalu mengarahkan hidupnya kepada Yahwe Allah Israel.

Yehezkiel menggunakan pengalaman para pemimpin di masa lalu sebagai cermin untuk membangun kembali kepemimpinan di tengah-tengah jemaat Israel dalam situasi serba baru di tanah pembuangan. Belajar dari masa lalu memberi kesempatan bagi mereka untuk mengerti bahwa apa yang

\footnotetext{
16 W. Eichrodt, Ezekiel, OTL, Philadelphia: WJKP, 1970, 301.

17 Iain M. Duguid, Ezekiel and the Leaders of Israel, VTSup 56, Leiden: Brill, 1994, 57.
} 
telah diperbuat oleh para pemimpin telah mendatangkan kehancuran bagi Israel. Dibutuhkan pemimpin-pemimpin baru yang menggembalakan Israel sesuai dengan marwah yang diberikan oleh Allah kepada mereka. Yeh. 34 sering dipandang sebagai program restorasi Israel dengan berfokus pada krisis kepemimpinan lokal. ${ }^{18}$

Di Yeh. 34:1-30, Allah berfirman melawan para pemimpin Israel, yakni para raja terakhir Yehuda menjelang pembuangan. Nubuat di Yeh. 34 ini sering dikelompokkan dalam nubuat-nubuat post-pembuangan yang muncul terutama di Yeh. 33-48. Nubuatnubuat ini dikelompokkan dalam jenis sastra nubuat keselamatan, yakni sebuah nubuat kenabian tentang pembebasan dari situasi yang menekan dan pemulihan kedamaian dan harmoni yang utuh. ${ }^{19}$ Nubuat Yeh 34 berperan sebagai transisi dari nubuat sebelum pembuangan yang berakhir dengan tekanan pada kemarahan Yahwe ke nubuat post-pembuangan yang lebih menampilkan nada-nada yang lebih lembut. ${ }^{20}$ Bab 34 membuka jalan bagi pesan agung akan pembaharuan dan harapan. ${ }^{21}$ Allah akan memulihkan peran-Nya sebagai Gembala Israel (34:1-31), memulihkan tanah (35:1-36:15), memulihkan kemuliaanNya (36:16-38), memulihkan umat-Nya (37:1-14), memulihkan perjanjian (37:1528), memulihkan supremasi-Nya (38:139:29), memulihkan kehadiran-Nya di antara umat-Nya (40:1-46:24), dan di Yeh. 47:1-48:35 Allah memulihkan kehadiranNya di tanah Israel. ${ }^{22}$ Kehancuran Israel

\footnotetext{
${ }^{18}$ Margaret S. Odell, Ezekiel, Smyth \& Helwys Bible Commentary, Macon, Georgia: Smyth \& Helwys, 2005, 423-4.

${ }^{19}$ Daniel I. Block,. The Book of Ezekiel, Grand Rapids: WB. Eerdmans, 1998, 268

${ }^{20}$ T. Ganzel, "The Descriptions of the Restoration of Israel in Ezekiel," Vetus Testamentum 60 (2010): 206.

21 Daniel I. Block, The Book of Ezekiel, 268.

22 Daniel I. Block, The Book of Ezekiel, 272.
}

dimengerti juga sebagai rusaknya wibawa Allah sebagai pemimpin Israel karena orangorang meragukan kuasa dan kekuatan-Nya sebagai penjamin hidup bangsa. Peristiwa pembuangan semakin meyakinkan orangorang yang meragukan Allah ini bahwa mereka sekarang bisa meninggalkan Allah dan menyembah dewa-dewi asing yang dianggap lebih kuat dari Allah. Nubuat kehancuran Yerusalem telah terwujud dengan kehancuran Yerusalem oleh Nebukadnezar dan pembuangan ke Babilonia dan kini nabi mengarahkan padangan ke hari-hari di depan yang menjanjikan pemulihan kemuliaan mereka oleh Allah. Allah pertama-tama akan memulihkan nama-Nya yang telah dicemarkan dan akan memulihkan kembali Israel sebagai umat yang tunduk kepada-Nya. Ia memulihkan wibawa-Nya sebagai pemimpin utama Israel.

Ayat 1-10 tampak sebagai sebuah kritikan post factum atas para pemimpin Israel yang menggembalakan diri sendiri, sementara ayat 11-16 menampilkan keputusan Allah untuk menarik kembali tanggungjawab penggembalaan dan Allah sendiri akan menggembalakan umat-Nya. Di ayat 1722 ditampilkan Allah yang akan menjadi hakim di antara umat yang digembalakanNya. Allah akan mengangkat Daud untuk menggembalakan umat-Nya (ay.23-24). Ia mengikatkan diri dengan umat-Nya dalam sebuah perjanjian untuk memberikan kesejahteraan kepada mereka. Allah adalah gembala dan Israel adalah domba gembalaan-Nya (ay.30-31).

\section{Dakwaan dan Ancaman Terhadap Para Gembala (ay.1-10)}

Dakwaan terhadapparagembala didahului dengan seruan "celakalah" yang ditujukan kepada mereka yang menggembalakan diri sendiri dan memperlakukan domba-domba 
dengan buruk, yakni dengan kekerasan dan kekejaman. Para raja disebut sebagai gembala. Gambaran raja sebagai gembala sudah sangat dikenal sejak zaman Sumeria ${ }^{23}$ dan Perjanjian Lama mengadopsi gambaran tersebut. Musa meminta kepada Allah agar memberi seorang pemimpin supaya umat tidak menjadi seperti domba tampa gembala (Bil. 27:17). Seperti umum dijumpai dalam teks-teks kenabian dalam Perjanjian Lama, para pemimpin Israel (raja) digambarkan sebagai gembala yang bertanggung jawab atas rakyat (Yes. 44:28; Yer. 2:8; 10:21; 23:1-6; 25:34-38; Mi. 5:4.5; Zac. 11:417). Kata gembala ini dipergunakan dalam Perjanjian Lama dengan banyak nuansa kepemimpinan: pemimpin militer seperti Yosua (Bil. 27:16-17), raja Koresh (Yes. 44:28); atau hakim Israel (2 Sam. 7:7); raja-raja secara khusus raja Daud (2 Sam. 5:2; Mzm. 78:70-71). Lebih dari semua itu, gembala digunakan untuk menggambarkan Allah yang adalah Gembala Israel (Mzm. 80:1; Kej. 49:24; Pengk. 12:11; Yeh. 34:2024). Gagasan tentang gembala yang berasal dari dunia peternakan itu dipergunakan secara metaforis untuk menggambarkan relasi antara Israel dan gembala mereka: Allah sebagai gembala yang menjamin hidup mereka dan para pemimpin yang tidak peduli, eksploitatif, egois. ${ }^{24}$

Dunia Timur Tengah Kuno mengenal gambaran seorang raja sebagai gembala dengan peran khusus sebagai pemberi makan dan penjaga kawanan. ${ }^{25}$ Seorang gembala bertugas memimpin kawanan, mencukupi kebutuhan kawanan, dan menjaga keamanan dan keselamatan mereka. Yehezkiel tidak mengidentifikasi

\footnotetext{
${ }^{23}$ Daniel I. Block, The Book of Ezekiel, 280.

${ }^{24}$ Ignatius M. C. Obinwa, I Shall Feed Them with Good Pasture, 265

${ }^{25}$ Margaret S. Odell, Ezekiel, 424.
}

siapakah yang dimaksud sebagai gembalagembala itu, tetapi mereka adalah para pemimpin Israel, yakni kelompok aristokrat yang karena kebijakan-kebijakan politik telah memporak-porandakan negeri dan membawa banyak orang ke pembuangan. ${ }^{26}$ Kedekatan Yehezkiel dengan pesan Yeremia memunculkan penafsiran bahwa gembalagembala ini adalah para pemuka bangsa di sekitar Zedekia, termasuk para penatua di Yerusalem (Yeh. 8), para pegawai (Yeh. 22:27), dan kemungkinan juga para nabi (Yeh. 13), serta para pemimpin Yehuda di pembuangan. ${ }^{27}$ Mereka mewakili kelompok penguasa yang telah mengeksploitasi, menceraiberaikan dan menyesatkan bangsa sampai ke pembuangan.

Para pemimpin Israel sudah dikritik oleh nabi di bab 13 dan 22 sehingga tidak mengherankan bahwa kritik atas mereka muncul kembali dengan nada lebih keras di bagian nubuat pemulihan Israel di bab 34 . Dalam rangkaian nubuat pemulihan oleh Allah di bab 34-48, bab 34 menampilkan Allah yang memulihkan kembali peran-Nya sebagai gembala bagi Israel. Allah adalah gembala yang hadir di tengah-tengah kawanan domba kepunyaan dan memerdekakan mereka dari para gembala yang korup dan abai. Kata yang digunakan untuk gembala adalah rō'êh yang merupakan partisipel aktif dari kata dasar rā' $\hat{a}$ yang berarti mengawasi, memelihara, menggembalakan. Dengan demikian, tanggungjawab utama seorang raja adalah mengawasi rakyatnya, dalam arti mengenali kebutuhan mereka, mencukupi makan dan minum, dan menjamin keselamatan mereka. Digambarkan bahwa Allah kecewa karena para gembala tidak menjalankan tugasnya dengan bertanggungjawab. Mereka gagal

\footnotetext{
${ }^{26}$ Margaret S. Odell, Ezekiel, 423.

${ }^{27}$ Daniel I. Block, The Book of Ezekiel, 282.
} 
dalam mengemban tanggung jawab atas domba-domba. ${ }^{28}$ Ayat 2-4 juga menampilkan kesalahan yang dilakukan oleh para gembala karena mereka tidak mendahulukan nasib domba-domba yang dipercayakan, tetapi hanya mementingkan diri sendiri (bdk. 34:3). Mereka egois dan tidak peduli dengan domba-domba (ay.4-5). Sebagai gembala, mereka justru memeras domba-domba dan menginjak-injak dengan kekejaman dan kekerasan. Sebagai konsekuensinya, Allah mencabut tanggungjawab yang diberikan kepada para gembala.

Tuduhan bahwa para gembala Israel justru menggembalakan diri mereka sendiri memuat dua pokok kesalahan para pemimpin yakni eksploitasi atas dombadomba dan ketidakpedulian pada nasib buruk yang dialami domba-domba. Para gembala menghisap domba-domba dan mengeruk keuntungan demi diri sendiri (34:2-3). Ada unsur eksploitasi dengan menggunakan kekuasaan demi memperoleh keuntungan dan kepentingan pribadi. Para gembala dikritik bahwa mereka “menggembalakan dirinya sendiri!"dan menghisap domba-domba dengan menikmati susunya, membuat pakaian dari bulunya, menyembelih yang gemuk, tapi dombadomba itu tidak digembalakan. Menikmati susu, menggunting bulu, dan menyembelih domba bukanlah praktek yang dicela dalam tradisi para gembala, tetapi dalam dakwaan di sini, tindakan-tindakan itu mengandung makna eksploitatif karena dilakukan oleh gembala-gembala yang menggembalakan diri sendiri. Mereka mengambil keuntungan dari domba-domba tanpa mau menjamin hidup domba-domba itu. Praktek buruk para gembala semakin ditampakkan dalam

${ }^{28}$ D. Bergant, The Collegeville Bible Commentary, Collegeville: The liturgical Press, 1989, 553. bagian kedua dari tuduhan terhadap mereka yakni ketidakpedulian para gembala terhadap domba-domba yang celaka. Menggembalakan diri sendiri tampak dalam kelalaian mereka dan ketidakpedulian terhadap domba-domba yang mengalami kesulitan: "Yang lemah tidak kamu kuatkan, yang sakit tidak kamu obati, yang luka tidak kamu balut, yang tersesat tidak kamu bawa pulang, yang hilang tidak kamu cari” (34:3). Mereka justru menginjak-injak dombadomba dengan kekerasan dan kekejaman.

Akibat eksploitasi dan ketidakpedulian para gembala, domba-domba mengalami malapetaka tragis (ay.5-6). Dombadomba tercerai berai dan dimangsa oleh binatang-binatang di hutan. Tanpa pengawasan seorang gembala, dombadomba akan terpisah dari kawanan, dan tanpa perlindungan gembala, mereka ada dalam bahaya menjadi mangsa binatang buas. Mereka tersesat tanpa seorang pun memperhatikan atau mencarinya. Mereka yang tercerai berai dan menjadi incaran binatang buas tidak bisa mengandalkan siapa pun karena tidak ada gembala yang peduli dan mencari mereka. Mereka tersesat tanpa pertahanan. Apa yang dialami oleh domba-domba ini semakin mengukuhkan tuduhan Allah terhadap para gembala bahwa mereka tidak bertanggungjawab atas tugas yang diberikan oleh Allah kepada mereka. Alih-alih menyatukan kawanan, mereka membuat domba-domba terceraiberai dan tersesat. Domba-domba yang tak digembalakan ini menghadapi bahaya besar menjadi mangsa binatang-binatang buas. Lebih parah lagi, mereka yang tersesat tidak memiliki kesempatan untuk kembali karena tidak ada yang memperhatikan dan mencarinya. Dengan kata lain, keselamatan domba sama sekali tidak menjadi perhatian para gembala. Hilangnya domba seolah-olah 
tidak menimbulkan kerugian sama sekali bagi para gembala. Mereka meninggalkan tanggung jawab untuk membawa dombadomba dalam kawanan untuk memperoleh makanan, untuk terhindar dari para pemangsa yang buas.

Karena para gembala melalaikan tanggung jawab sebagai gembala, Allah mendatangkan ancaman-ancaman terhadap mereka (ay.710). Allah akan berperkara melawan para pemimpin yang tidak bertanggung jawab. Berperkara melawan Allah merupakan saat berbahaya karena tidak ada orang yang akan bertahan di hadapan kebenaran Allah. Tidak ada orang yang benar di hadapan Allah, apalagi para pemimpin Israel yang jelasjelas sudah mengabaikan tanggung jawab mereka. Kalau Allah berperkara melawan mereka, mereka pasti ada dalam pihak yang kalah. Allah sendiri akan mengambil kembali domba-domba-Nya serta melepaskan mereka dari mulut para pemimpin yang serakah ini. Atas kelalaian dan sikap tidak bertanggung jawab mereka, Allah akan memberhentikan mereka sebagai gembala Israel dan mereka tidak akan diizinkan lagi untuk menggembalakan Israel (Yer. 23:2).

\section{Allah, Gembala Israel (ay.11-16)}

Setelah mengambil kembali tugas untuk menggembalakan Israel dari para pemimpin yang tidak bertanggungjawab, kini Allah sendirilah yang menggembalakan Israel. Di antara sekian banyak metafor tentang Allah di Perjanjian Lama, metafor tentang Allah sebagai gembala sangatlah dikenal (Mzm. 23). Ia adalah gembala dan gunung batu Israel (Kej. 49:24). Mzm. 78:52s juga menggambarkan Allah yang menggembalakan Israel dalam perjalanan di padang gurun. Ia mempimpin Israel maka Israel tidak takut. Perjanjian Lama juga akrab dengan gambaran gembala yang merupakan pekerjaan pokok orang-orang Israel. Tokoh-tokoh utama Perjanjian Lama yang adalah gembala, seperti Abraham, Ishak, Musa, Daud, Amos.

Domba dan ternak gembalaan sepenuhnya bergantung kepada para gembala untuk memperoleh kandang, perlindungan dari ancaman, rumput dan air, serta kesembuhan dari penyakit dan kelemahan. Domba tidak akan bertahan tanpa gembala karena mereka mencari rumput di padang yang penuh dengan bahaya: cuaca dingin atau kekeringan, tebing curam, binatang pemangsa dan musuh. Bagi binatang gembalaan yang bergantung pada dirinya, gembala menampakkan perhatian dan perlindungannya: menjaganya di waktu malam, menghalau binatang pemangsa, membawa ke padang rumput dan sumber air. Hidup gembala tidak pernah terpisahkan dari ternak gembalaannya. Pekerjaan menggembalakan ternak membuat mereka harus terpisah dari hidup perkotaan, berkelompok kecil di padang gembalaan, menghadapi ancaman alam dan ancaman lawan. Dengan demikian, seorang gembala adalah pemimpin dan penjamin hidup bagi kawanan yang mengorbankan dirinya bagi kawanannya. Inilah ide dasar yang juga muncul dalam metafor Allah sebagai gembala Israel. Allah adalah pemilik kawanan, pemimpin yang membawa mereka ke sumber kehidupan, dan penjamin perlindungan dari bahaya dan kematian.

Di dalam bagian ancaman terhadap para gembala (ay. 11-16), figur para gembala tak bertanggungjawab yang dilawan oleh Allah di ay. 7-10 tidak tampil lagi karena kini yang tampil sepenuhnya adalah Allah yang menjadi gembala. Ketika Allah mengambil alih tugas penggembalaan, Allah tampil dalam kontras dengan para pemimpin Israel. Allah menjadi 
gembala yang ideal (ay.11-31). Kontras pertama tampak dalam tanggungjawab Allah yang besar untuk menjaga kesatuan dan keselamatan domba-domba gembalaanNya. Allah memperhatikan dan mencari, menyelamatkan mereka dari segala tempat, membawa keluar dari tengah bangsabangsa, mengumpulkan mereka dari negeri-negeri dan mengumpulkan mereka ke tanahnya, menggembalakan mereka di gunung-gunung Israel, membiarkan mereka berbaring dan rumput subur menjadi makanannya. Pernyataan-pernyataan ini menunjuk pada nasib Israel di pembuangan yang akan digembalakan oleh Allah. Mereka akan diambil oleh Allah dari tempat mereka tercerai-berai dan dibawa kembali ke gunung-gunung Israel. Allah akan membawa mereka kembali ke tanah yang telah Ia janjikan kepada umat terpilih ini. Kalau para pemimpin masa lalu telah membuat mereka tercerai berai ke tanah asing dan menjadi mangsa bangsa asing, kini Allah akan menuntun mereka kembali ke tanah leluhur.

Para gembala Israel yang lalai dan mengabaikan domba-domba yang malang digantikan oleh Allah yang mencari yang hilang, membawa pulang yang tersesat, membalut yang luka, menguatkan yang sakit, melindungi yang gemuk dan kuat. Bagian ini menampakkan kontras antara tindakan para gembala dan tindakan Allah terhadap domba-domba yang ada dalam kemalangan. Di ayat 4 muncul rangkaian tindakan: a) tidak kamu kuatkan (hizzeq), b) tidak kamu obati (rippē'), c) tidak kamu balut (hābaš), d) tidak kamu bawa pulang (hēšŝb), e) tidak kamu cari (biqqēš). Rangkaian ketidakpedulian para gembala dalam skema a, b, c, d, e ini ada dalam kontras dengan kepeduliaan Allah bagi para domba: e') mencari (biqqēš), d') membawa pulang (hēšŝb), c') membalut (hāābaš), b') sakit, a') menguatkan (hizzeq) yang menampilkan skema e', d', c', b', a'. Perbedaan kecil ada pada a' dan b' yang tidak menampilkan tindakan Allah bagi si sakit (mengobati) dan tidak menyebut siapa yang dikuatkan oleh Allah (yang lemah). Dengan demikian, rangkaian kontras tindakan para gembala di ayat 4 dan tindakan Allah di ayat 16 ada dalam paralelisme simetris kontradiktoris.

\section{Pengadilan Atas Domba-domba Gemuk (ay. 17-24)}

Setelah perkara dengan para gembala (yakni raja Israel) diselesaikan oleh Allah, kini Allah mengarahkan tuduhan-Nya terhadap sekelompok orang di antara bangsa Israel yang disebut-Nya sebagai dombadomba yang gemuk yang diperlawankan dengan domba yang kurus; antara domba jantan dan kambing jantan. Rupanya kesulitan yang dihadapi oleh kawanan domba Israel tidak hanya muncul dari rajaraja yang tidak bertanggung jawab, tetapi juga dari sekelompok pemuka masyarakat yang juga mementingkan diri sendiri. Sama seperti dalam kasus para gembala Israel (ay.2-10), Allah pertama-tama mengajukan dakwaan terhadap domba-domba gemuk dalam kawanan-Nya. Siapakah yang sedang diserang oleh Allah? Mereka adalah sekelompok orang di dalam kawanan Allah yang melakukan kejahatan terhadap saudarasaudaranya: menghabiskan padang rumput terbaik, menginjak-injak padang rumput yang lain dengan kakinya, meminum air yang jernih dan mengeruhkan air itu dengan kakinya. Domba yang gemuk menunjuk pada sekelompok elit dalam masyarakat Israel yang juga menampilkan keserakahan dengan mengabaikan mereka yang lemah. Mereka adalah para penatua dan juga para 
pejabat pemerintahan. ${ }^{29}$ Pertanyaan kunci muncul di ay.19, "Apakah domba-domba-Ku seharusnya memakan rumput yang sudah diinjak-injak kakimu dan meminum air yang sudah dikeruhkan kakimu?" Mereka sudah memiliki dalam kelimpahan, tetapi mereka masih merebut bahkan menginjak-injak sumber kehidupan (rumput) sesama yang miskin.

Atas dakwaan di ayat 17-19, Allah tidak mengajukan ancaman hukuman terhadap para pemimpin ini. Yang ada adalah pernyataan bahwa Allah akan menjadi hakim antara domba yang gemuk dan domba yang kurus. Menjadi hakim disini berarti bahwa Allah akan memulihkan kembali keadilan, menghilangkan sebabsebab perpecahan relasi dalam komunitas, dan memulihkan kedamaian di antara para domba. ${ }^{30}$ Yang gemuk dan kuat tidak akan lagi mendesak yang lemah dengan lambung, bahu dan tanduk, serta menghalau mereka keluar kandang. Allah akan melindungi yang lemah supaya tidak menjadi mangsa yang kuat dan Allah sendiri yang akan memulihkan keadaan mereka. Untuk mewujudkan rencana pemulihan tersebut, Allah akan mengangkat satu gembala yang akan menggembalakan mereka yakni Daud. Yahwe akan menjadi Allah mereka, dan Daud menjadi raja atas mereka. Sekali lagi, Allah berpihak pada mereka yang lemah dengan memberikan bagi mereka raja yang akan menggembalakan mereka bagi Allah.

Pengangkatan Daud sebagai gembala baru Israel merupakan langkah lanjut yang diambil oleh Allah setelah Ia mencabut wewenang penggembalaan dari para raja Israel. Daud dianggap sebagai raja ideal yang menggembalakan Israel sebagai

\footnotetext{
${ }^{29}$ Daniel I. Block, The Book of Ezekiel, 293.
}

${ }^{30}$ Daniel I. Block, The Book of Ezekiel, 293. perpanjangan tangan Allah. Pengangkatan Daud berarti pemulihan kembali damai dan kesejahteraan di antara Israel yang kalah dan terbuang. Daud juga menjadi simbol kesatuan nasional ketika Israel masih menjadi satu bangsa yang utuh. Dengan demikian, pengangkatan Daud sebagi satu gembala menjadi nubuat pemulihan kesatuan kawanan yang telah terpecah sejak kematian Salomo; masing-masing digembalakan oleh raja-raja yang tidak lagi berpihak pada Allah dan melakukan apa yang jahat di mata Allah.

\section{Perjanjian Damai (ay.25-31)}

Kecaman-kecaman nabi terhadap para pemimpin menampilkan sebuah kritik sosial yang keras, seperti saat Yehezkiel mengecam Tirus. Memang dalam hal ini kecaman terhadap pemimpin Tirus tidak hanya tertuju pada raja semata, melainkan juga terhadap Tirus sebagai sebuah bangsa. Sebagai daerah yang kaya, Tirus hidup dalam kecongkakan dan kesombongan. Juga dalam kelimpahannya, raja Tirus mengumpulkan harta untuk dirinya (Yeh. 28:4) sehingga menjadi cerminan adanya ketimpangan sosial besar antara pemimpin dan rakyatnya.

Kritik sosial yang keras dilancarkan oleh Yehezkiel untuk melawan raja-raja yang menggembalakan diri mereka sendiri. Dengan tegas, Yehezkiel menyatakan kemarahan Allah atas para gembala Israel yang tidak peduli pada domba-domba yang digembalakan dan hanya mementingkan kepentingan diri sendiri (Yeh. 34:1-30). Di Yeh. 34:1-30, digambarkan pelanggaran para gembala Israel yang tidak menjalankan tugasnya dengan baik. Mereka melupakan domba-domba dan mementingkan kepentingan pribadi-Nya. Ia tidak peduli dengan nasib domba dan hanya mencari kepuasan pribadinya. 


\section{KESIMPULAN}

Warta kenabian Yehezkiel terkait erat dengan situasi sosio-religius Israel sebagai bangsa terbuang yang diajak untuk memandang masa depan mereka sebagai masa depan yang akan dipulihkan oleh Allah. Allahlah yang menjauhkan mereka dari Yerusalem, tetapi Allah pula yang akan memulihkan martabat mereka sebagai bangsa dengan membawa mereka kembali ke tanah leluhur. Salah satu kenyataan yang akan dipulihkan oleh Allah adalah wibawa Allah sebagai gembala Israel yang justru telah dirong-rong oleh para pemimpin (yakni raja dan pemuka bangsa) kerena mereka mencerai-beraikan kawanan yang dipercayakan oleh Allah kepada mereka. Allah akan mengambil alih tugas penggembalaan, dan Allah sendirilah yang akan menggembalakan Israel.

Selain merestorasi kewibawaan Allah atas Israel, kritik terhadap para gembala juga merestorasi nasib Israel yang disesatkan oleh para gembala sehingga masuk dalam kehancuran menjadi bangsa yang dibebaskan oleh Allah sendiri dari cengkeraman pemimpin yang tidak adil. Pemulihan ini senada dengan tema pemulihan (restorasi Israel) yang mencakup tema-tema tentang pengumpulan kembali Israel, pengudusan nama Allah yang suci di hadapan bangsabangsa, kembali ke tanah Israel, dan pengakuan bahwa Yahwe adalah Allah. ${ }^{31}$ Satu unsur yang umum dijumpai dalam nubuat kenabian tetapi tidak tampil dalam nubuat pemulihan oleh Yehezkiel adalah sesal dan pertobatan atas dosa masa lampau serta pengampunan Allah sebagai tanggapan atas pertobatan Israel. ${ }^{32}$ Restorasi Isreal, yakni pulangnya orang-orang buangan ke Israel, tidak terjadi karena pertobatan mereka tetapi karena kehendak Allah untuk menguduskan nama-Nya di hadapan bangsa-bangsa. ${ }^{33}$ Tema yang muncul di bab 34 adalah tema tentang Allah yang memelihara kawanan-Nya dan membawa kembali mereka yang telah tersesat. Pada akhir bab, Allah menyatakan Israel sebagai domba gembalaan-Nya dan menyatakan diri sebagai Allah bagi Israel (ay.31).

\footnotetext{
31 T. Ganzel, "The Descriptions of the Restoration of Israel in Ezekiel," Vetus Testamentum 60 (2010): 200.

32 T. Ganzel, "The Descriptions of the Restoration of Israel in Ezekiel," 200.

33 T. Ganzel, "The Descriptions of the Restoration of Israel in Ezekiel,” 200.
} 


\section{DAFTAR PUSTAKA:}

Bergant, D. The Collegeville Bible Commentary, Collegeville: The liturgical Press, 1989.

Block, Daniel I. The Book of Ezekiel, Grand Rapids: WB. Eerdmans, 1998.

Beyond The River Chebar. Studies in Kingship and Eschatology in the Book of Ezekiel, Cambridge: James Clarke \& Co, 2013.

Clark, Terry R. I Will Be King over You. The Rhetoric of Divine Kingship in the Book of Ezekiel. Piscataway, NJ: Gorgias Press, 2014.

Duguid, Iain M. Ezekiel and the Leaders of Israel, VTSup 56, Leiden: Brill, 1994.

Eichrodt, W. Ezekiel, OTL, Philadelphia: WJKP, 1970.

Ganzel, T. "The Descriptions of the Restoration of Israel in Ezekiel," Vetus Testamentum 60 (2010): 197-211.

Nissinen, Martti. "(How) Does the Book of Ezekiel Reveal Its Babylonian Context?" Die Welt des Orients 45 (2015): 85-98.

Obinwa, Ignatius M. C. "I Shall Feed Them with Good Pasture" (Ezek 34:14): The Shepherd Motif in Ezekiel 34. Its Theological Import and Socio-political Implications, FB 125; Wurzburg: Echter, 2012.
Odell, Margaret S. Ezekiel, Smyth \& Helwys Bible Commentary, Macon, Georgia: Smyth \& Helwys, 2005.

Rom-Shiloni, D. "Ezekiel as the Voice of the Exiles and Constructor of Exilic Ideology," Hebrew College Annual 76 (2005): 1-45.

Rom-Shiloni, D. - Corrine Carvalho. "Introduction," Die Welt des Orients 45 (2015): 3-9.

Sarwar, Chaudhary I. "Future of Ethically Effective Leadership," Journal of Business Ethics 113 (2013): 81-89.

Strine, C. A. Sworn Enemies. The Divine Oath, the Book of Ezekiel, and the Polemics of Exile, Berlin: De Gruyter, 2013.

Strine, C. A. - C. L. Crouch, "Yhwh's Battle against Chaos in Ezekiel: The Transformation of Judahite Mythology for a New Situation," Journal of Biblical Literature 132 (2013): 883-903.

Tsang, S., "A Call to Leadership: Character Study of Ezekiel and the Temple Staff," CGST, 44 (2008): 151-172. 